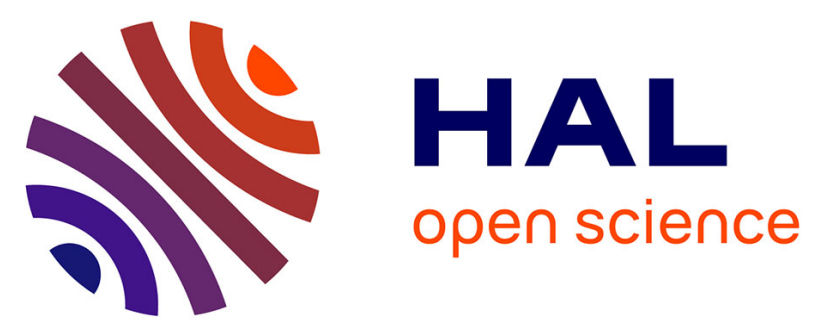

\title{
Testing of gas flow measurement methods to characterize substances which emit flammable or toxic gases in contact with water
}

\author{
Agnès Janes, Guy Marlair, Douglas Carson
}

\section{- To cite this version:}

Agnès Janes, Guy Marlair, Douglas Carson. Testing of gas flow measurement methods to characterize substances which emit flammable or toxic gases in contact with water. Process Safety and Environmental Protection, 2016, 100, pp.232-241. 10.1016/j.psep.2016.01.016 . ineris-01862940

HAL Id: ineris-01862940

https://hal-ineris.archives-ouvertes.fr/ineris-01862940

Submitted on 28 Aug 2018

HAL is a multi-disciplinary open access archive for the deposit and dissemination of scientific research documents, whether they are published or not. The documents may come from teaching and research institutions in France or abroad, or from public or private research centers.
L'archive ouverte pluridisciplinaire HAL, est destinée au dépôt et à la diffusion de documents scientifiques de niveau recherche, publiés ou non, émanant des établissements d'enseignement et de recherche français ou étrangers, des laboratoires publics ou privés. 


\title{
Testing of Gas Flow Measurement Methods to Characterize Substances which Emit Flammable or Toxic Gases in Contact with Water
}

\author{
Agnès JANÈS ${ }^{1}$, Guy MARLAIR ${ }^{1}$, Douglas CARSON ${ }^{1}$ \\ ${ }^{1}$ INERIS, Accidental Risks Division, Parc ALATA, BP 2, F-60550 Verneuil en Halatte, \\ France
}

Corresponding author: Agnès JANÈS (E-mail address: agnes.janes@ineris.fr)

\begin{abstract}
:
Selecting the most appropriate flow measurement techniques with related devices to characterize potentially hazardous chemicals which emit flammable or toxic gases due to their hydro-reactivity poses a difficult but required task for official classification of such materials. This paper offers a careful examination of three such potential methods that differ from each other by the flow rate measurement device which includes one manual and two automatic systems. Experiments for comparative testing and validation limits have been defined and carried out for two known hydro-reactive chemicals: aluminum chloride and sodium borohydride. The main conclusions are reported here. From the results obtained, the possible selection of the best investigated methods is suggested according to performance based criteria.
\end{abstract}

Keywords: Dangerous when wet - Water-reactivity - Reaction with Water - Hazardous hydro-reactive properties - Classification-testing protocols - Flammability and toxicity of released gases 


\section{Introduction and context}

In a hazard assessment for the handling, storage, or transport of materials that may produce dangerous gases when wet, the experimental determination of the produced gas flow rate must be performed. When the dangerous gas is flammable, the published UN N.5 test is used. This test is described in the Manual of Tests and Criteria of United Nations (UN, 2008) and mandatory used by international transport regulations as well as the classification of dangerous substances and mixtures according to Globally Harmonized System (GHS) (UN, 2013). In Europe, this test is required for the Classification, Labeling, and Packaging regulations (CLP) (European Parliament and of the Council, 2008). The scientific background and the classification schemes of substances which in contact with water emit flammable gases were extensively described by the authors in a previous publication (Janès et al., 2012).

The UN N.5 test is based on a two step process: 1) three different preliminary tests are performed on small amounts of sample to determine if a violent reaction occurs in contact with water 2) if such a reaction does not occur, the gas flow rate produced must be measured experimentally. The classification threshold is fixed at 1 liter of flammable gas per kilogram of substance per hour. If the chemical identity of the gas is unknown, the gas should be tested for flammability. One major difficulty of the current N.5 method is that it does not sufficiently describe the test conditions and therefore too much freedom is left to the potential users leading to a large degree of diversity in actual laboratory practices. Indeed, in previous work (Janès et al., 2012), it was shown that the variation of some parameters influence the results obtained. These influences could be so great that the uncertainty of the measurement can be on the order of the classification threshold. Improvement of test conditions, setting more precisely some of these influential test parameters and optimization of the experimental apparatus have been suggested (Janès et al., 2012). 
In the case of substances or mixtures which emit toxic gases in contact with water, no standardized method is yet available however greatly needed insofar that CLP regulations (European Parliament and of the Council, 2008) have introduced this new hazard class. Considering the uncertainties related to the results obtained using the current N.5 method, its direct transposition for the generation of toxic gases cannot be envisaged. Indeed, the classification threshold will be much lower than for flammable gases because of the acute toxicity of certain gases in even a modest overall gas release. It is anticipated though that an improved method derived from the UN N.5 test protocol could be used, if the accuracy and fidelity of gas flow measurement can be achieved.

Several alternative methods to the N.5 test were proposed recently. Rosenberg et al (Rosenberg et al., 2012) and (Rosenberg et al., 2013) have described an alternative procedure that relies on the variation of the mass of displaced water due to the evolution of gas during the reaction of the sample with water. Their stated motivation is indeed the lack of precision of the N.5 test protocol. This was also the measurement principle that was selected for RoundRobin tests organized by the German Bundesanstalt für Materialforschung und -prüfung (BAM) in 2011 (Kunath et al., 2011). The measuring apparatus was calibrated by means of the reaction of a hydrochloric acid solution with magnesium powder, wherein the flow of released hydrogen can be calculated. The results obtained indicate a discrepancy between the measured and the theoretical volume of $4 \%$. The related uncertainty on the result from the reaction of magnesium with demineralized water was estimated at $17 \%$ and the detection limit was reported to be in the order of 3-4 mL.

Later, Smith et al. (Smith et al., 2013) and (Smith et al., 2014) carried out an investigation with a proposed test method based on the reaction taking place in a closed constant volume vessel and deducing by calculation the gas release rate from the pressure elevation in the test vessel. A very detailed description of the system was given with a thorough analysis of results 
obtained on ten different materials producing flammable or toxic gases in contact with water. Eventually, some classification criteria based on the gas release rate combined with the toxicity of the gas were suggested (Smith et al., 2014). However, it is necessary to exclude a modification of the reaction mechanism with water that is a consequence of the high pressure in the test vessel, which could therefore influence the result and subsequently the classification of the material tested. Such influence was highlighted in 2012 on aluminum (Janès et al., 2012).

The present work is dedicated to the investigation of an innovative test protocol with three different devices, aiming to achieve accurate and reliable measurement of potentially low gas release rate resulting from the reaction of a sample with water. The metrological performances of this protocol and apparatuses are also characterized. These new elements constitute potential breakthroughs that could significantly improve the UN N.5 test method, and possibly provide an alternative method intended for the classification of substances or mixtures which, in contact with water, emit toxic gases.

\section{Experimental}

\subsection{Test apparatus}

The experimental apparatus consists mainly of an assembly of glassware composing a $25 \mathrm{~mL}$ conical flask, another glass-made piece with a membrane cap at the end, and a gas collection pipe, as shown in Figure 1. First, the test sample if put in the flask and then the water is injected using a $1 \mathrm{~mL}$ syringe.

$<$ Figure 1: Experimental apparatus consisting of a conical flask and a piece of glassware with a gas collection pipe and a membrane cap.> 
A major difference with current UN N.5 procedure is that the dropping funnel is not used in this new set-up. This system reduces the overall free volume of the experimental system, which then reduces the uncertainties on the measured gas flow rate due to the thermal expansion gas when the ambient temperature or atmospheric pressure vary during test runs. The system is assembled before the injection of water and therefore a reaction can take place between the two reactants. As in the case when a dropping funnel is used, it is necessary to subtract the contribution of the water injection to the raw data.

The stopwatch is started at the time of the injection of water into the flask.

\subsection{Tested gas flow measurement systems}

Three innovative experimental devices were identified and assumed particularly interesting for their potential to reduce the uncertainties of the gas volume released. These devices are described below.

\subsubsection{MGC-1 volume meter (PMMA cell) filled with Silox fluid}

The MGC-1 is represented in Figure 2. It consists in a volumetric device and an automatic flow meter, which contains a cell immersed in synthetic oil, which collects the gas discharged from the reaction between the sample and water. An accumulated gas volume reaching 3.26 mL induces fulfilling of the elemental measurement cell. Each time such event arrives, the cumulative recording of one more volume increment is obtained. The released gas escapes to the open air by another pipe. This cell is not compatible with corrosive gases, since it is made of polymethyl methacrylate (PMMA).

The fluid that fills the cell is a polydimethyl siloxane named "Silox" and available by the company RITTER. The material safety data sheet indicates an incompatibility of Silox with chloride. 
The "RIGAMO" acquisition software records each increment point whenever the cell is overloaded. The device also provides a digital display of the cumulative gas volume recorded over time.

To be consistent in the calculation of gas flow released, only the cumulative gas volume released over time was used. Indeed, the operating manual does not specify the method of deriving the instantaneous flow rate displayed by calculation.

The cost of the MGC-1 volumetric meter was about 2,000 euros in 2013. The cost of the associated computer can be estimated at less than 500 euros. The operating cost of the equipment is estimated to be less than 300 euros per year, taking into account the replacement of the working fluid. The use of the MGC-1 volumetric meter is simple, and it requires very limited training (less than an hour is our estimate).

$<$ Figure 2: View of the automatic volume meter MGC-1 (PMMA cell) filled with Silox fluid.>

\subsubsection{MGC-1 volume meter (PVDF cell) filled with Calrix fluid}

This automatic volume meter, which is displayed in Figure 3, is identical to that described above, except that:

- the material constituting the cell, vinylidene polyfluoride (PVDF), is resistant to corrosive gases,

- the calibrated volume of gas accumulation inducing the cell overload is equal to $2.98 \mathrm{~mL}$,

- The fluid that fills the cell, "Calrix", is also available from the company RITTER. It is a synthetic fluid containing the element fluorine for use with corrosive gases and shows no chemical incompatibility with chlorides. 
The cost of the MGC-1 volumetric meter was on the order of 2,500 euros in 2014. The cost of the associated computer can be estimated to be less than 500 euros. The operating cost of the equipment is estimated to be less than 300 euros per year, taking into account the replacement of the working fluid. The use of the MGC-1 volumetric meter is simple, and it requires similar limited training of less than an hour.

<Figure 3: View of the automatic volume meter MGC-1 (PVDF cell) filled with Calrix fluid.>

\subsubsection{Burettes filled with Calrix fluid}

With this equipment, the tests were performed using a home-made metering system consisting of liquid-filled $50 \mathrm{~mL}$ burettes, graduated to $0.1 \mathrm{~mL}$, allowing gas volume to be measured at atmospheric pressure. The equipment is shown in Figure 4. The released gas volume is read at atmospheric pressure at regular intervals during the test period, aligning the liquid vessel and the water level in the burette connected to the test flask. The room temperature is also noted. This measuring device is particularly simple to use and does not require any significant staff training. Its cost is estimated to be less than 500 euros. The operating cost of the equipment is estimated to be less than 300 euros per year, taking into account the replacement of the working fluid.

$<$ Figure 4: View of the burettes filled with Calrix fluid. $>$

These three systems are so-called "constant pressure" systems, in so far as the reaction is maintained at atmospheric pressure during the tests. We have not included in this study measuring devices in a constant volume system, since the tests conducted earlier had shown that the results obtained in a constant volume system may in some cases be very different 
from those obtained in a constant pressure system, due to overpressure driven phenomena (Janès et al., 2011).

\subsection{Procedure for evaluating accuracy and fidelity of measurement systems tested}

The tests of metrological performances consisted in measuring the volume of hydrogen or air generated by a calibrated automatic syringe pump, set to different target flow values.

The main objective is to track representative flow rates liable to be obtained during classification tests of substances and mixtures and which trigger dangerous levels of gases by contact with water.

Selected target flow rates in our study are based on i) the classification thresholds pertaining to existing regulations (flammability issue) or expected toxicity thresholds and ii) anticipated range of sample masses to be tested according to existing experience. For flammable gases potentially emitted by reaction with water, regulatory thresholds according to GHS transposition in the EU CLP regulation (European Parliament and of the Council, 2008) were used. In the case of toxic gases which may be generated in contact with water, due the absence of regulatory classification thresholds, the assumption used is that the order of magnitude of the expected rate of gas release is less than $1 / 10$ of the regulatory classification threshold of substances or mixtures which emit flammable gases on contact with water.

This assumption appears to be significantly more severe than the flow rate threshold proposed in (Smith et al. 2014), which is fixed at $1 \mathrm{~L}^{\mathrm{k}} \mathrm{kg}^{-1} \cdot \mathrm{h}^{-1}$, i.e. equal to the current threshold corresponding to the classification of substances and mixtures which emit flammable gases in contact with water. 
The selected flow rates are reported in Table 1, which associates these thresholds and expected range of test mass of sample in routine experiments.

$<$ Table 1: Selected flow rates for evaluation of accuracy and fidelity of measurement systems tested, associated with classification thresholds and probable sample masses tested.>

In the case of calibration tests performed with hydrogen, three target flow rates were selected as these values would act as thresholds in the context of the classification of substances and mixtures which release flammable gases on contact with water:

- $600 \mathrm{~mL} / \mathrm{h}(10 \mathrm{~mL} / \mathrm{min})$,

- $100 \mathrm{~mL} / \mathrm{h}$,

- $\quad 5 \mathrm{~mL} / \mathrm{h}$.

In the case of burettes filled with Calrix fluid, the highest flow rate could not be tested, due to the high viscosity of the fluid. Indeed, the time required for the measurements does not follow precisely enough the evolution of the volume released. This observation clearly shows the limitations of this measurement system.

For calibration tests using air, the target flow rate values selected are lower, to be representative of the range of those corresponding to the classification of substances and mixtures which emit toxic gases on contact with water:

- $\quad 2 \mathrm{~mL} / \mathrm{h}$,

- $1 \mathrm{~mL} / \mathrm{h}$,

- $\quad 0.5 \mathrm{~mL} / \mathrm{h}$.

The MGC-1 volume meter (PMMA cell) filled with silox fluid was not tested due to potentially corrosive gases released under these conditions. 
The repeatability of the results was calculated on the basis of three test runs for each test condition, in accordance with UN N.5 test method relating requirements.

Given the observed flow rate values during real condition tests on sodium borohydride which revealed significantly higher than those selected as target values calibration tests, an additional verification of the two measurement systems was carried out with air at a target flow rate of $25 \mathrm{~mL} / \mathrm{h}$. This verification did not lead to any concern in the sense that measured value was very close to actual flow rate injected by the syringe. As it was performed as verification test, it was not repeated and therefore the date were not used for uncertainties determination displayed in Tables 5 to 7.

\subsection{Procedure used during genuine tests on water-reactive materials}

Tests were carried out by introducing a measured mass of material in a $25 \mathrm{~mL}$ Erlenmeyer flask. A defined amount of water was injected using a $1 \mathrm{~mL}$ syringe through the membrane cap of the glassware.

The reaction between aluminum chloride and water produces hydrochloric acid, whereas the reaction between sodium borohydride and water produces hydrogen.

Table 2 summarizes the experimental conditions of the tests performed on aluminum chloride. Tests conducted on sodium borohydride and experimental conditions are given in Table 3.

<Table 2: Test numbering and relating experimental conditions for aluminum chloride.>

<Table 3: Test numbering and relating experimental conditions for sodium borohydride.> 


\subsection{Material samples}

Sample selection was made according to two main purposes: i) for the evaluation of metrology performance; ii) for testing actual water-reactive response according to the protocol.

\subsubsection{Evaluation of accuracy and fidelity of measurement systems under investigation}

Experiments intended for assessing the metrological performance of the developed experimental systems were performed using air and hydrogen. This choice was dictated by the following considerations: Firstly, from a hydrodynamic behavior perspective, air is considered as a good model gas to mimic toxic gases that may be generated by materials, which in contact with water emit toxic gases. Secondly, materials, especially metals, which in contact with water invokes the flammability of gas classification, frequently generate hydrogen.

Moreover, this gas is most prone to leakage during measurements and thus constitutes a conservative approach.

\subsubsection{Test run on actual water-reactive materials}

Tests conducted under real operational experimental conditions in this system were performed on two chemical substances selected from those used as reference materials by Smith et al. (Smith et al., 2013). Further, they were supplied by the same provider, allowing fully consistent comparisons. We selected sodium borohydride and aluminum chloride. Their characteristics are reported in Table 4.

$<$ Table 4: List and characteristics of substances used to test developed experimental systems in real conditions.> 


\subsection{Temperature conditions}

All tests were performed in our laboratory, at controlled room temperature, and sheltered from sunlight.

Temperature was measured during each test. Its range was from 20.5 to $25^{\circ} \mathrm{C}$, varying by no more than $2 \mathrm{~K}$ during a given test.

\section{Results and discussion}

\subsection{Evaluation of the accuracy and fidelity of tested measurement systems}

Under each experimental condition, the measured cumulated volume was plotted as a function of time and a linear regression by the least squares method was used to assess the scatter of flow rates.

Tables 5 to 7 summarize the results of the tests conducted in this work. The values reported are rounded off after calculation.

$<$ Table 5: Gas flow rate measurement data (based on 3 runs) obtained by use of the automatic volume meter MGC-1 (PMMA cell) filled with Silox fluid.>

<Table 6: Gas flow rate measurement data (based on 3 runs) obtained using the automatic volume meter MGC-1 (PVDF cell) filled with Calrix fluid.>

<Table 7: Gas flow rate measurement data (based on 3 runs) obtained using the burettes filled with Calrix fluid.>

The metrological characteristics of the different measurement systems tested are reported in Table 8. 
The detection limit is equal to the quantification limit. Indeed, for any device it is not possible to observe a lower gas release than its quantification limit.

<Table 8: Summary of metrological characteristics of tested experimental devices.>

Figure 5 shows the relative difference between the measured flow rate and fixed flow rate, for each evaluated device.

$<$ Figure 5: Relative difference between the measured flow rate and target flow rate.>

Generally, the difference between the measured and the target flow rate is higher when the flow rate is low. This could be due to leakage located at the connections between the different parts of the measurement system.

The burettes filled with Calrix fluid overestimates the gas flow rate by about $10 \%$ for very low flow rates. This could be related to the high viscosity of the fluid.

Figure 6 shows the standard deviation on the measured flow rate, as a function of the target flow rate, which, generally speaking, decreases as the gas flow rate increases. On the basis of three test runs, the analysis of the data reveals quite good repeatability, which also somewhat varies according to the configurations tested.

$<$ Figure 6: Standard deviation on the measured flow rate, as a function of the flow rate.>

These results make it possible to select the measurement devices adapted and specify the expected repeatability, according to the intended use to the classification of material which in 
contact with water emits flammable or toxic gases. The acceptable apparatuses are indicated in the Tables 9 and 10.

<Table 9: Choice of devices in the context of classification of substances and mixtures which in contact with water emit flammable gases and expected repeatability.>

$<$ Table 10: Choice of devices in the context of classification of substances and mixtures which in contact with water emit toxic gases and expected repeatability.>

\subsection{Operational testing on actual water-reactive samples}

\subsubsection{Aluminum chloride}

The gas flow was measured using the MGC-1 volume meter (PVDF cell) filled with Calrix fluid.

After water injection, a vigorous reaction occurs and an aerosol appears into the flask. The gas flow shown in Figure 7 is calculated on the basis of successive volume measurements. As it appears in this figure, the results obtained are widely scattered. Two reasons have been identified as a potential explanation. The very high solubility of $\mathrm{HCl}$ in water may be one aspect of the issue. Also, as exemplified in Figure 7, the vigorous reaction observed between test substance and water may develop with significantly different kinetics in the same test conditions. As a result, successive determinations of instantaneous gas release rate may appear somewhat inconsistent, but would likely not change the final regulatory classification. <Figure 7: Gas flow obtained with aluminum chloride.>

For aluminum, Smith et al. (Smith et al., 2013) reported a gas flow calculated on the basis of pressure evolution exceeding 3600 L.(kg.min) $)^{-1}$ or $2.16^{*} 10^{5}$ L.(kg.h $)^{-1}$, obtained in the first 
5 seconds after initiation of reaction. The pressure drop after the peak indicates a very rapid absorption of the gas released in water.

Thus, the results obtained with the two protocols are similar and of the same order of magnitude.

\subsubsection{Sodium borohydride}

The gas flow was measured using i) the MGC-1 volume meter (PVDF cell), filled with Calrix fluid, and ii) burettes filled with Calrix fluid.

The gas emission rate measured as a function of time is represented in Figures 8 to 10.

<Figure 8: Gas flow rate obtained with sodium borohydride - water/sample mass ratio of 2.>

$<$ Figure 9: Gas flow rate obtained with sodium borohydride - water/sample mass ratio of 4.>

$<$ Figure 10: Gas flow rate obtained with sodium borohydride - water/sample mass ratio of 8.>

Generally, the release rate obtained using the burettes filled with Calrix fluid reveals slightly higher values than that observed with the automatic MGC-1 volume meter. In the case of burettes, measurements can only be performed regularly during the first eight hours and then again during the next day. This disadvantage is not encountered with automatic systems such as the MGC-1 volume meter.

In the two measurement systems cases, the maximum release rate is reached in the early hours of testing, before decreasing.

It is observed that the gas flow varies with the weight ratio between sodium borohydride and water. This statement was also made by Smith et al. (Smith et al., 2013), as seen graphically in Figure 11. The maximum release rates obtained with the two experimental protocols appear to be on the same order of magnitude. 
$<$ Figure 11: Comparison of gas flow rate obtained with sodium borohydride as a function of water/sample mass ratio.>

\section{Conclusion}

This work was aimed to determine the metrological performances of three gas flow measurement devices, in the context of the classification of substances and mixtures which in contact with water emit dangerous gases. The test protocol used for this study was an adaptation of the published UN N.5 test method.

The experimental program consisted of two parts. The first part targeted the evaluation of metrological performances using the three volume measurement devices selected under controlled hydrogen or air flow conditions and to analyze and compare the results to the known fixed flows.

In a second step, these apparatuses were tested under operational conditions for measuring the volume of hydrochloric acid or hydrogen generated by reactions between water and aluminum chloride on the one hand and sodium borohydride on the other. The results of measurements of volume and flow calculations are consistent with published data on the same products, which used different test conditions.

The results show that the proposed test protocol and the three measurement methods selected provide sufficient accuracy and fidelity on gas flow release to be used in the context of the classification of substances and mixtures which in contact with water emit flammable or toxic gases.

Moreover, the use of the proposed alternative protocol, based on the principle of a reaction at atmospheric pressure in a constant pressure environment, avoids the possible influence of pressure on the reaction rate of the material tested with water when the reaction occurs at elevated pressure. 


\section{Acknowledgements}

This work was partially supported financially by the French Ministry of Environment, Ecology and Durable Development. We also thank G. Smith and BAM colleagues for the fruitful exchanges we have had on the matter.

\section{References}

European Parliament and of the Council, 2008. Regulation (EC) No 1272/2008 of 16 December 2008 on classification, labeling and packaging of substances and mixtures, amending and repealing Directives 67/548/EEC and 1999/45/EC, and amending Regulation (EC) No 1907/2006.

Janès A., Marlair G., Carson D., Chaineaux J., 2012. Towards the improvement of UN N.5 test method relevant for the characterization of substances which in contact with water emit Flammable Gases. J. Loss Prev Process Ind. 25, 524-534.

Kunah, K., Lüth, P., Uhlig, S., 2011. Interlaboratory test on the method UN test N.5/EC A.12 "Substances which, in contact with water, emit flammable gases”, Berlin.

Rosenberg M., Michael-Schulz H., Wehrstedt K. D., Malow M.,2012. Validation of UN Test Method N.5. Mary Kay O’Connor Process Safety Center, 15 ${ }^{\text {th }}$ Annual International Symposium, October 23-25, 2012, College Station, Texas, USA.

Rosenberg M. Michael-Schulz H., Wehrstedt K. D., Malow M, 2013. Validation of the UN Test Method N.5. J. Loss Prev Process Ind. 30, 282-286.

Smith M., Chun J., Nemzer A., Richard B., 2013. LLC, HMCRP, HM-14, Test Procedures and Classification Criteria for Release of Toxic Gases from Water-Reactive Materials, DRAFT, Interim Reporting - Phase II (Task 4) Experimental Work - February-April 2013, Washington D.C. 
Smith M., Chun J., Nemzer A., Richard B., 2014. Test Procedures and Classification Criteria for Release of Toxic Gases from Water-Reactive Materials, HMCRP Report 13, Transportation Research Board, Washington D.C., http://www.trb.org/Publications/Blurbs/171449.aspx, last access May $21^{\text {st }} 2015$

UNO, 2008. Manual of Test and Criteria. Fourth revised edition, ref. ST/SG/AC.10/11/Rev.4, Geneva.

UNO, 2013. Globally Harmonized System of Classification and Labeling of Chemicals (GHS). Fifth revised edition, Geneva. 
Table 1: Selected flow rates for evaluation of accuracy and fidelity of measurement systems tested, associated with classification thresholds and probable sample masses tested.

\begin{tabular}{|c|c|c|c|c|}
\hline \multirow{6}{*}{$\begin{array}{l}\text { Sample } \\
\text { mass (g) }\end{array}$} & \multicolumn{4}{|c|}{ Substances or mixtures which on contact with water emit: } \\
\hline & \multicolumn{3}{|c|}{ Flammable gases } & \multirow{2}{*}{$\begin{array}{l}\text { Toxic gases } \\
\text { Assumption }\end{array}$} \\
\hline & Category 1 & Category 2 & Category 3 & \\
\hline & Threshold: & Threshold: & Threshold: & Threshold: \\
\hline & 10 L.min ${ }^{-1} \cdot \mathrm{kg}^{-1}$ & $20 \mathrm{~L} \cdot \mathrm{h}^{-1} \cdot \mathrm{kg}^{-1}$ & $1 \mathrm{~L} \cdot \mathrm{h}^{-1} \cdot \mathrm{kg}^{-1}$ & $0.1 \mathrm{~L} \cdot \mathrm{h}^{-1} \cdot \mathrm{kg}^{-1}$ \\
\hline & \multicolumn{4}{|c|}{ Corresponding flow rate $\left(\mathrm{mL} \cdot \mathrm{h}^{-1}\right)$} \\
\hline 50 & 30,000 & 1,000 & 50 & 5 \\
\hline 40 & 24,000 & 800 & 40 & 4 \\
\hline 30 & 18,000 & 600 & 30 & 3 \\
\hline 20 & 12,000 & 400 & 20 & 2 \\
\hline 10 & 6,000 & 200 & 10 & 1 \\
\hline 5 & 3,000 & 100 & 5 & 0.5 \\
\hline 2 & 1,200 & 40 & 2 & 0.2 \\
\hline 1 & 600 & 20 & 1 & 0.1 \\
\hline
\end{tabular}


Table 2: Test numbering and relating experimental conditions for aluminum chloride.

\begin{tabular}{|c|c|c|}
\hline \# test & $\begin{array}{c}\text { Aluminum chloride mass } \\
(\mathrm{g})\end{array}$ & Water volume (mL) \\
\hline 1 & 0.5 & 0.5 \\
\hline 2 & 0.5 & 0.75 \\
\hline 3 & 0.5 & 1.5 \\
\hline 4 & 0.5 & 1.5 \\
\hline 5 & 0.5 & 2 \\
\hline 6 & 0.5 & 2 \\
\hline 7 & 0.5 & 2.5 \\
\hline 8 & 0.5 & 4 \\
\hline 9 & 0.5 & 1 \\
\hline
\end{tabular}

Table 3: Test numbering and relating experimental conditions for sodium borohydride.

\begin{tabular}{|c|c|c|}
\hline \# test & $\begin{array}{c}\text { Sodium borohydride mass } \\
(\mathrm{g})\end{array}$ & Water volume (mL) \\
\hline 1 & 0.25 & 0.5 \\
\hline 2 & 0.25 & 0.5 \\
\hline 3 & 0.25 & 1 \\
\hline 4 & 0.25 & 2 \\
\hline 5 & 0.25 & 2 \\
\hline 6 & 0.25 & 1 \\
\hline
\end{tabular}


Table 4: List and characteristics of substances used to test developed experimental systems in real conditions.

\begin{tabular}{|c|c|c|c|}
\hline Substance & CAS & $\begin{array}{c}\text { Gas emitted when } \\
\text { wet }\end{array}$ & Supplier and reference \\
\hline $\begin{array}{c}\text { Sodium } \\
\text { borohydride } \\
\left(\mathrm{NaBH}_{4}\right)\end{array}$ & $16940-66-2$ & Hydrogen $\left(\mathrm{H}_{2}\right)$ & $\begin{array}{l}\text { Sigma-Aldrich } \\
\text { Aluminum chloride, 98\% } \\
\text { Ref. 206911-100G }\end{array}$ \\
\hline $\begin{array}{c}\text { Aluminum } \\
\text { chloride }\left(\mathrm{AlCl}_{3}\right)\end{array}$ & 7446-70-0 & $\begin{array}{l}\text { Hydrogen chloride } \\
(\mathrm{HCl})\end{array}$ & $\begin{array}{l}\text { Sigma-Aldrich } \\
\text { Sodium borohydride, } \\
\text { reagentplus, 99\% } \\
\text { Ref. } 213462-25 G\end{array}$ \\
\hline
\end{tabular}


Table 5: Gas flow rate measurement data (based on 3 runs) obtained by use of the automatic volumeter MGC-1 (PMMA cell) filled with Silox fluid.

\begin{tabular}{|l|c|c|c|}
\hline \multirow{2}{*}{ Gas } & \multicolumn{3}{c|}{$\mathrm{H}_{2}$} \\
\cline { 2 - 4 } & $\mathrm{mL} / \mathrm{h}$ & $\mathrm{mL} / \mathrm{h}$ & $\mathrm{mL} / \mathrm{min}$ \\
\hline Target Flow rate & 5 & 100 & 10 \\
\hline Mean value & 4.21 & 97.17 & 9.81 \\
\hline Absolute deviation compared to target rate & -0.79 & -2.83 & -0.19 \\
\hline Relative deviation compared to target rate & $-5.81 \%$ & $-2.83 \%$ & $-1.93 \%$ \\
\hline Absolute standard deviation & 1.05 & 6.83 & 0.15 \\
\hline
\end{tabular}


Table 6: Gas flow rate measurement data (based on 3 runs) obtained using the automatic volumeter MGC-1 (PVDF cell) filled with Calrix fluid.

\begin{tabular}{|c|c|c|c|c|c|c|}
\hline \multirow{2}{*}{ Gas } & \multicolumn{5}{|c|}{$\mathrm{H}_{2}$} & \multicolumn{2}{c|}{ Air } \\
\cline { 2 - 7 } & $\mathrm{mL} / \mathrm{h}$ & $\mathrm{mL} / \mathrm{h}$ & $\mathrm{mL} / \mathrm{min}$ & $\mathrm{mL} / \mathrm{h}$ & $\mathrm{mL} / \mathrm{h}$ & $\mathrm{mL} / \mathrm{h}$ \\
\hline $\begin{array}{c}\text { Target } \\
\text { Flow rate }\end{array}$ & 5 & 100 & 10 & 0.5 & 1 & 2 \\
\hline $\begin{array}{c}\text { Mean } \\
\text { value }\end{array}$ & 4.56 & 100.71 & 9.85 & 0.28 & 0.84 & 1.86 \\
\hline $\begin{array}{c}\text { Absolute } \\
\text { deviation } \\
\text { compared } \\
\text { to target } \\
\text { rate }\end{array}$ & -0.44 & 0.71 & -0.15 & -0.22 & -0.16 & -0.14 \\
\hline $\begin{array}{c}\text { Relative } \\
\text { deviation } \\
\text { compared } \\
\text { to target } \\
\text { rate }\end{array}$ & $-8.84 \%$ & $0.71 \%$ & $-1.52 \%$ & $-43.96 \%$ & $-16.33 \%$ & $-7.16 \%$ \\
\hline $\begin{array}{c}\text { Absolute } \\
\text { standard } \\
\text { deviation }\end{array}$ & 0.34 & 0.71 & 0.03 & 0.10 & 0.07 & \\
\hline
\end{tabular}


Table 7: Gas flow rate measurement data (based on 3 runs) obtained using the burettes filled with Calrix fluid.

\begin{tabular}{|c|c|c|c|c|c|}
\hline \multirow{2}{*}{ Gas } & \multicolumn{3}{|c|}{$\mathrm{H}_{2}$} & \multicolumn{3}{c|}{ Air } \\
\cline { 2 - 6 } & $\mathrm{mL} / \mathrm{h}$ & $\mathrm{mL} / \mathrm{h}$ & $\mathrm{mL} / \mathrm{h}$ & $\mathrm{mL} / \mathrm{h}$ & $\mathrm{mL} / \mathrm{h}$ \\
\hline Flow rate & 5 & 100 & 0.5 & 1 & 2 \\
\hline Mean value & 4.73 & 98.76 & 0.55 & 1.16 & 2.22 \\
\hline $\begin{array}{c}\text { Absolute } \\
\text { deviation } \\
\text { compared to } \\
\text { fixed rate }\end{array}$ & -0.27 & 1.24 & 0.05 & 0.16 & 0.22 \\
\hline $\begin{array}{c}\text { Relative } \\
\text { deviation } \\
\text { compared to } \\
\text { fixed rate }\end{array}$ & $-5.32 \%$ & $1.24 \%$ & $10.05 \%$ & $16.25 \%$ & 10.79 \\
\hline $\begin{array}{c}\text { \# Trials } \\
\text { Absolute } \\
\text { standard } \\
\text { deviation }\end{array}$ & 3 & 3 & 3 & 3 & 3 \\
\hline
\end{tabular}


Table 8: Summary of metrological characteristics of tested experimental devices.

\begin{tabular}{|l|c|c|c|c|c|}
\hline \multicolumn{1}{|c|}{ Device } & $\begin{array}{c}\text { Data } \\
\text { acquisition } \\
\text { mode }\end{array}$ & $\begin{array}{c}\text { Direct flow } \\
\text { rate } \\
\text { recording }\end{array}$ & $\begin{array}{c}\text { Resolution } \\
(\mathrm{mL})\end{array}$ & $\begin{array}{c}\text { Detection } \\
\text { limit (equal } \\
\text { to the } \\
\text { quantification } \\
\text { limit) (mL) }\end{array}$ & $\begin{array}{c}\text { Maximal } \\
\text { capacity } \\
(\mathrm{mL})\end{array}$ \\
\hline $\begin{array}{l}\text { Burettes } \\
\text { filled with } \\
\text { Calrix fluid }\end{array}$ & Manual & No & 0.1 & 0.1 & $\begin{array}{c}50 \\
\text { (manual } \\
\text { purge } \\
\text { possible) }\end{array}$ \\
\hline $\begin{array}{l}\text { MGC-1 } \\
\text { (PMMA } \\
\text { cell) filled } \\
\text { with Calrix } \\
\text { fluid }\end{array}$ & Automatic & Yes & 2.98 & 2.98 & \begin{tabular}{c} 
No limitation \\
\hline $\begin{array}{l}\text { MGC-1 } \\
\text { (PVDF cell) } \\
\text { filled with } \\
\text { Silox fluid }\end{array}$
\end{tabular} \\
\hline
\end{tabular}


Table 9: Choice of devices in the context of classification of substances and mixtures which in contact with water emit flammable gases and expected repeatability.

\begin{tabular}{|l|l|l|l|}
\cline { 2 - 4 } \multicolumn{1}{c|}{} & \multicolumn{2}{c|}{ Substances and mixtures which in contact with water emit } \\
\cline { 2 - 4 } & \multicolumn{1}{|c|}{ Category 3 } & \multicolumn{1}{c|}{ Category 2 } & \multicolumn{1}{c|}{ Category 1 } \\
\hline \multirow{2}{*}{ Suitable devices } & $\begin{array}{l}\text { Burettes filled with } \\
\text { Calrix fluid } \\
\text { Automatic volume } \\
\text { meter MGC-1 } \\
\text { (PVDF cell) filled } \\
\text { with Calrix fluid }\end{array}$ & $\begin{array}{l}\text { Burettes filled with } \\
\text { Calrix fluid } \\
\text { Automatic volume } \\
\text { meter MGC-1 } \\
\text { (PVDF cell) filled } \\
\text { with Calrix fluid }\end{array}$ & $\begin{array}{l}\text { Automatic } \\
\text { volume meter } \\
\text { MGC-1 (PVDF } \\
\text { cell) filled with } \\
\text { Calrix fluid }\end{array}$ \\
\hline $\begin{array}{l}\text { Repetability (on the basis } \\
\text { of 3 repeated tests) }\end{array}$ & $<8 \%$ & $<1 \%$ & $<1 \%$ \\
\hline
\end{tabular}


Table 10: Choice of devices in the context of classification of substances and mixtures which in contact with water emit toxic gases and expected repetability.

\begin{tabular}{|l|l|}
\cline { 2 - 2 } \multicolumn{1}{c|}{} & \multicolumn{1}{c|}{$\begin{array}{c}\text { Substances and mixtures which in contact with water emit } \\
\text { toxic gases }\end{array}$} \\
\hline Suitable devices & $\begin{array}{l}\text { Burettes filled with Calrix fluid } \\
\text { Automatic volume meter MGC-1 (PVDF cell) filled with } \\
\text { Calrix fluid }\end{array}$ \\
\hline $\begin{array}{l}\text { Repetability (on the basis } \\
\text { of } 3 \text { repeated tests) }\end{array}$ & About $10 \%$ \\
\hline
\end{tabular}




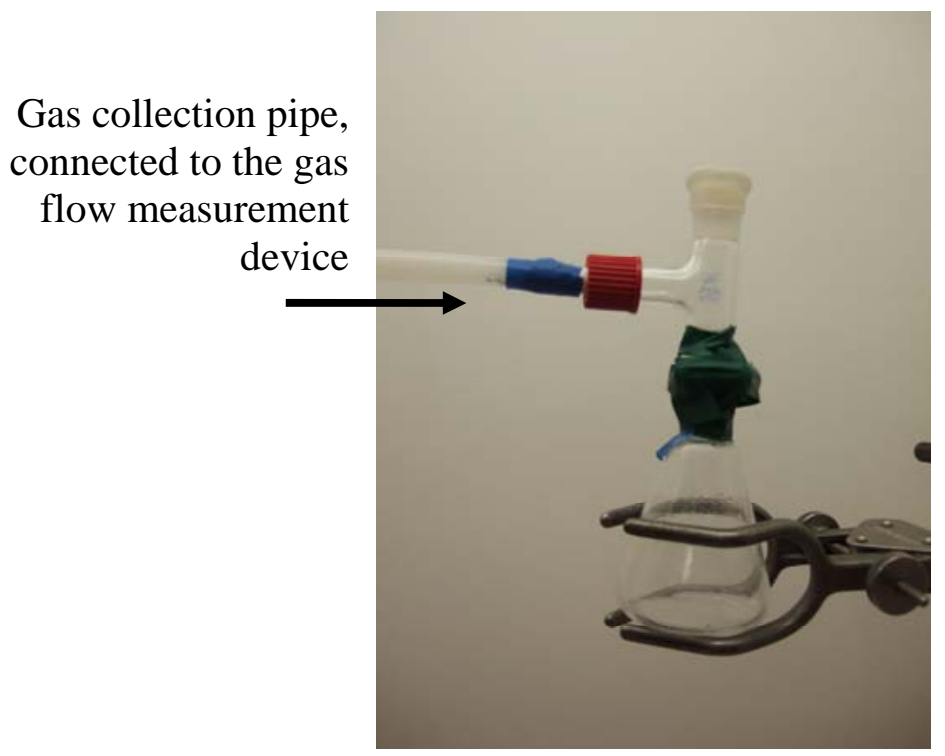

Figure 1: Experimental apparatus consisting of a conical flask and a piece of glassware with a gas collection pipe and a membrane cap.
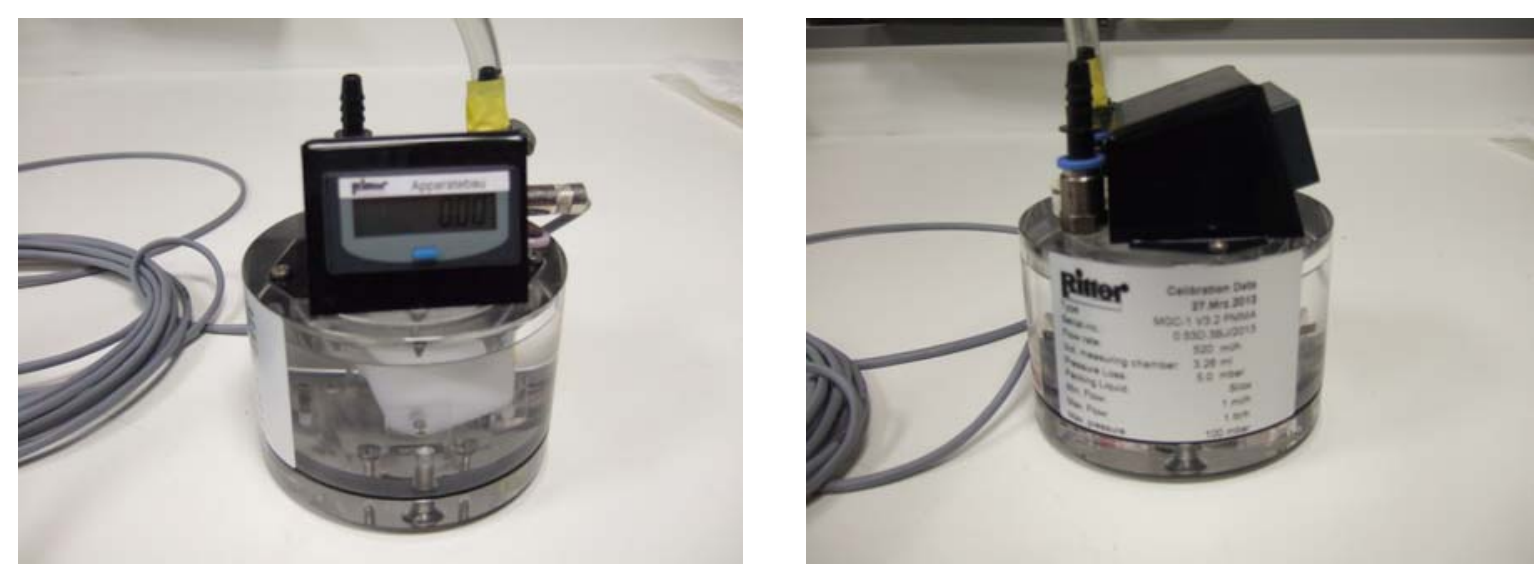

Figure 2: View of the automatic volumeter MGC-1 (PMMA cell) filled with Silox fluid. 

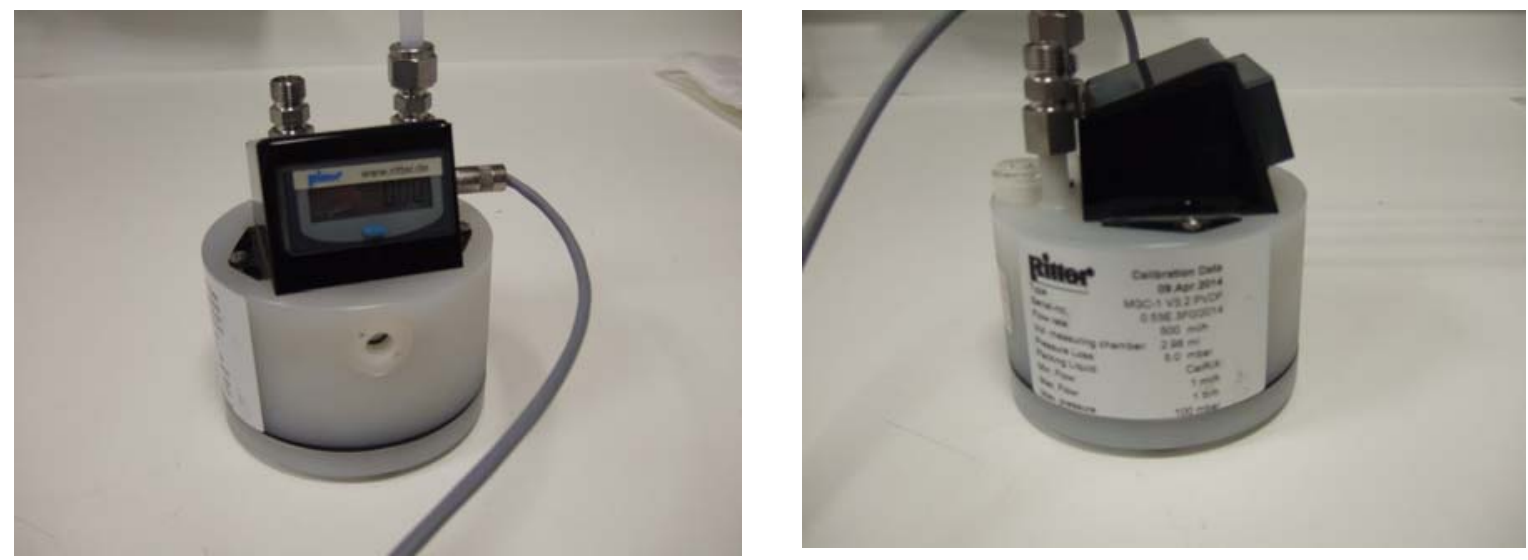

Figure 3: View of the automatic volumeter MGC-1 (PVDF cell) filled with Calrix fluid.
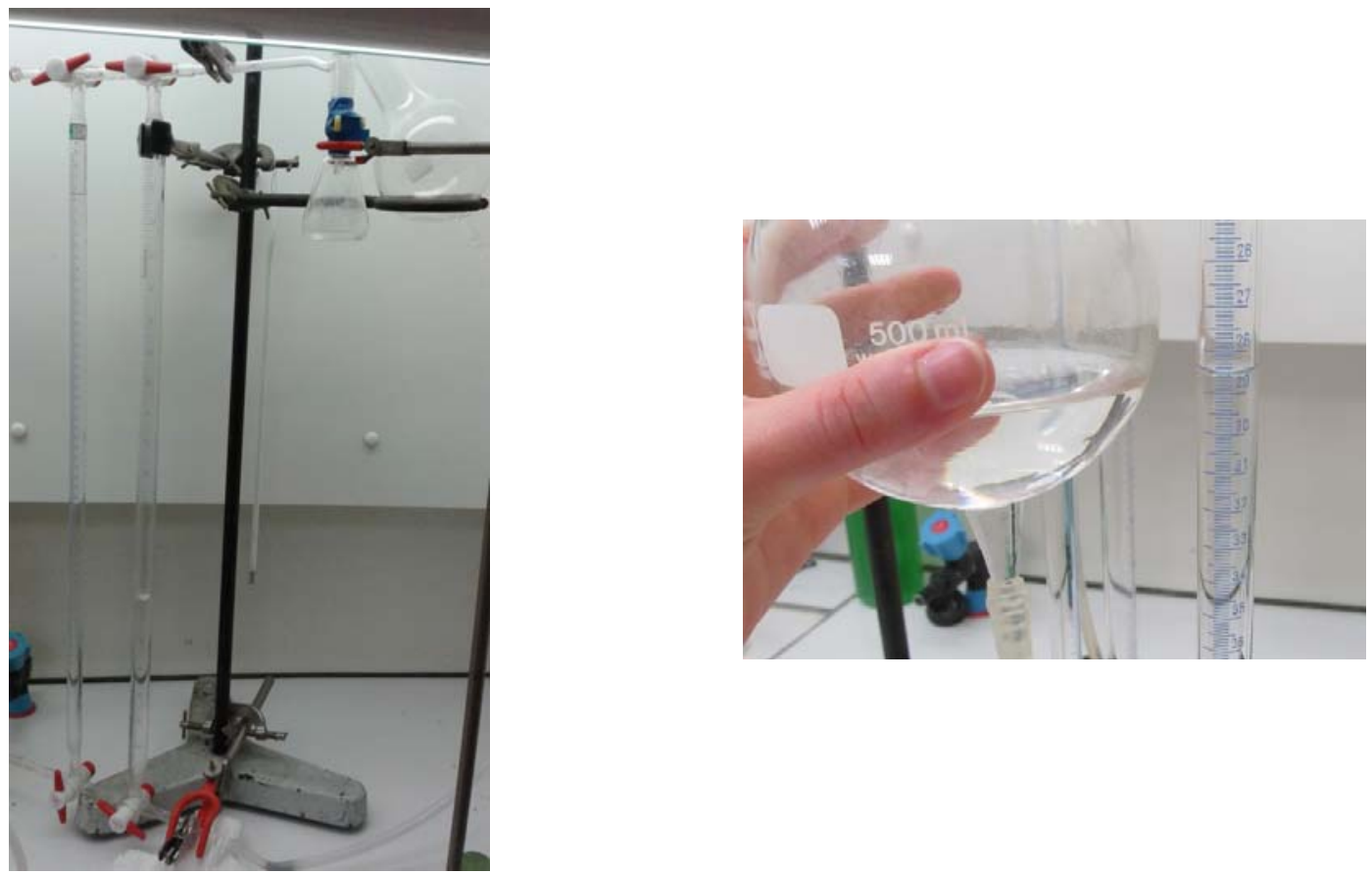

Figure 4: View of the burettes filled with Calrix fluid. 


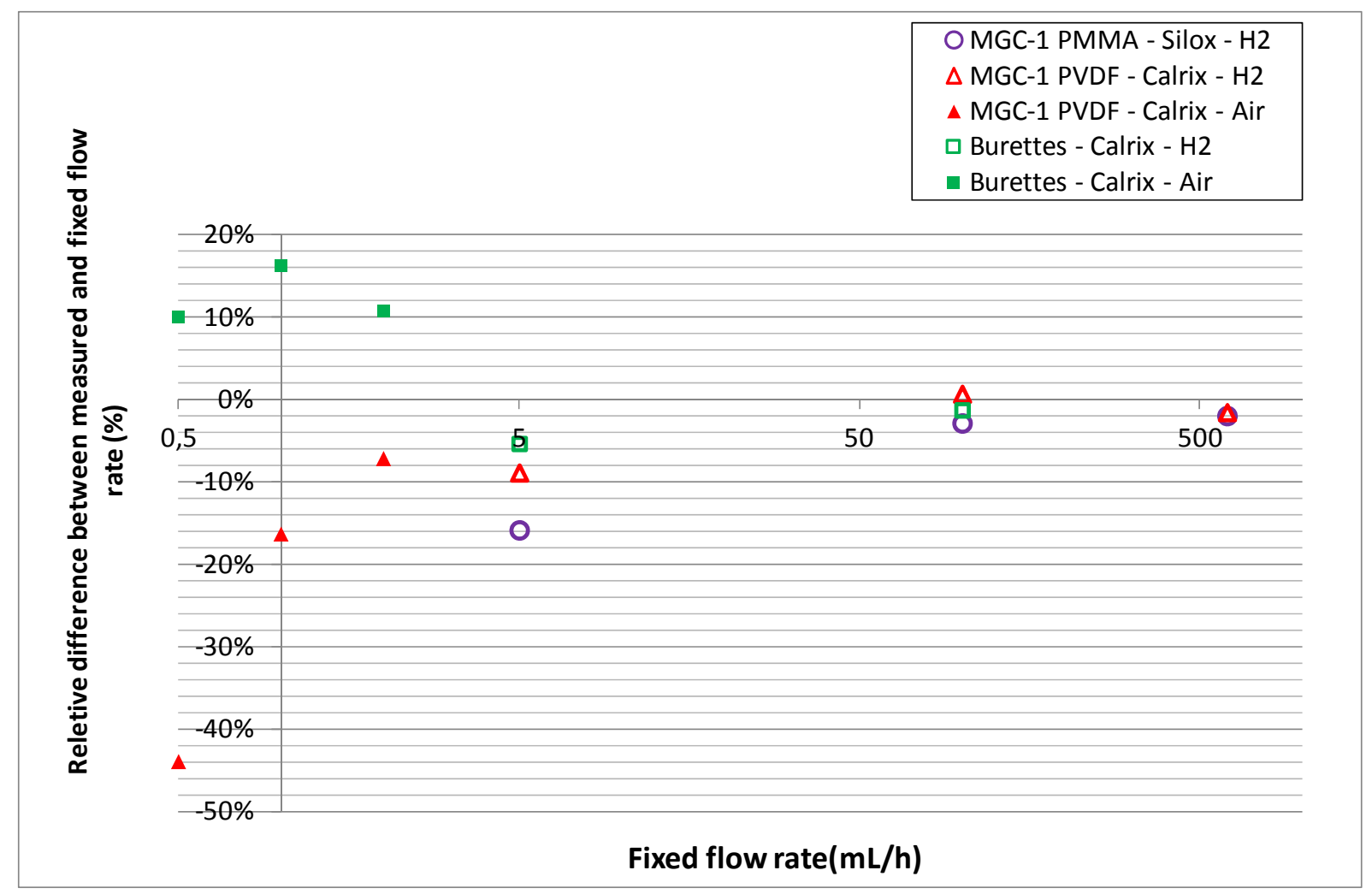

Figure 5: Relative difference between the measured flow rate and target flow rate.

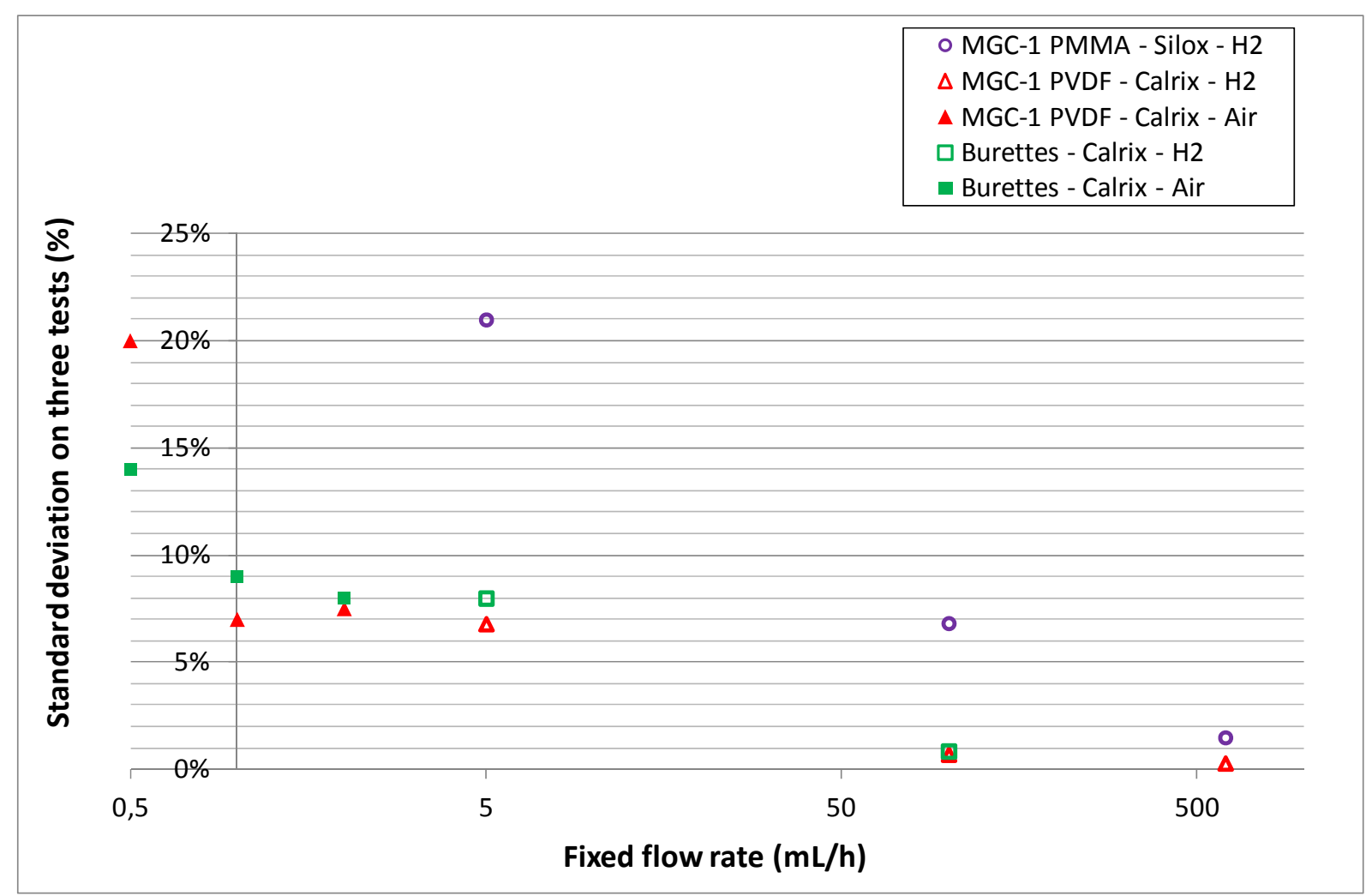

Figure 6: Standard deviation on the measured flow rate, as a function of the flow rate. 


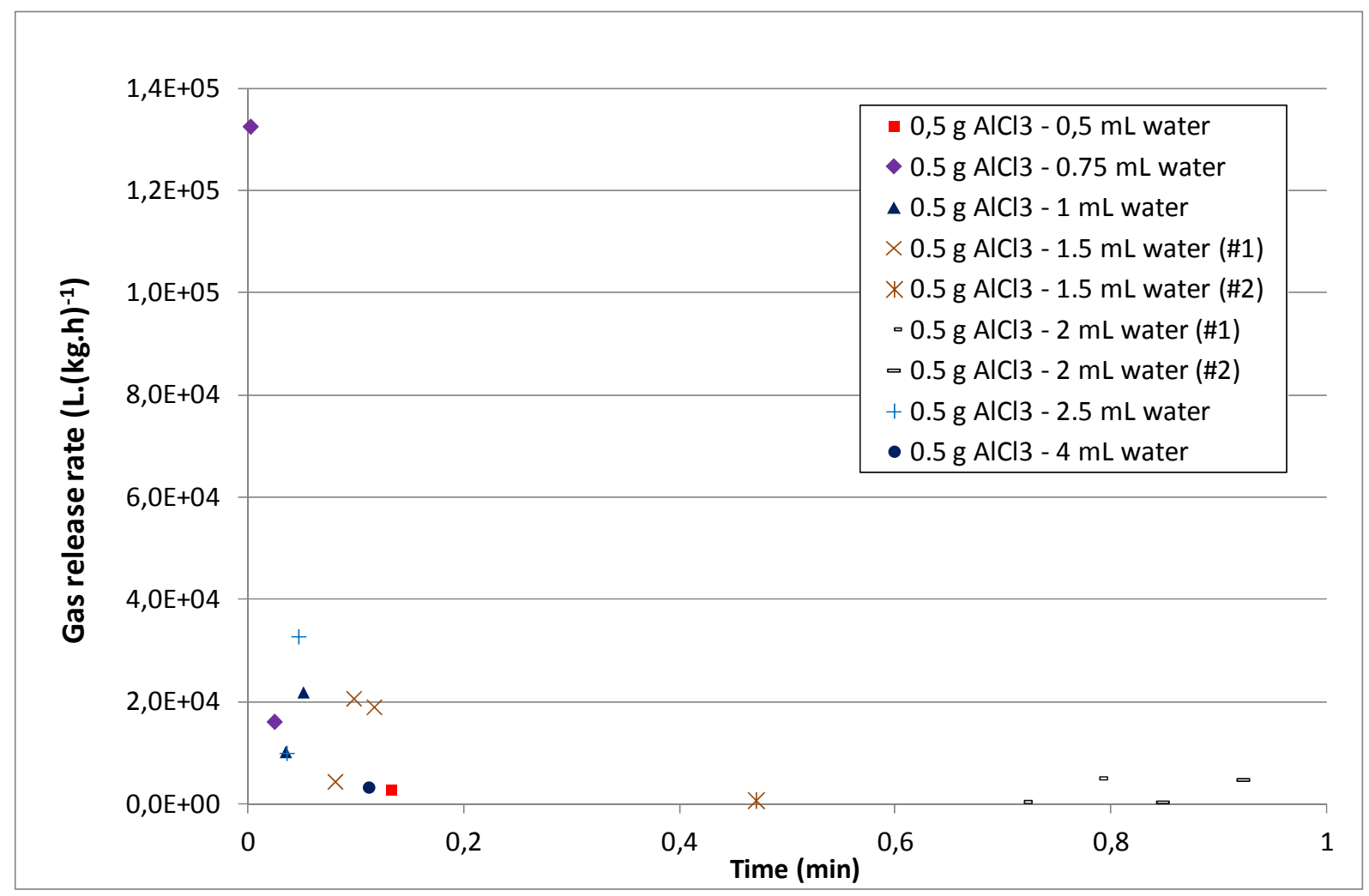

Figure 7: Gas flow obtained with aluminum chloride.

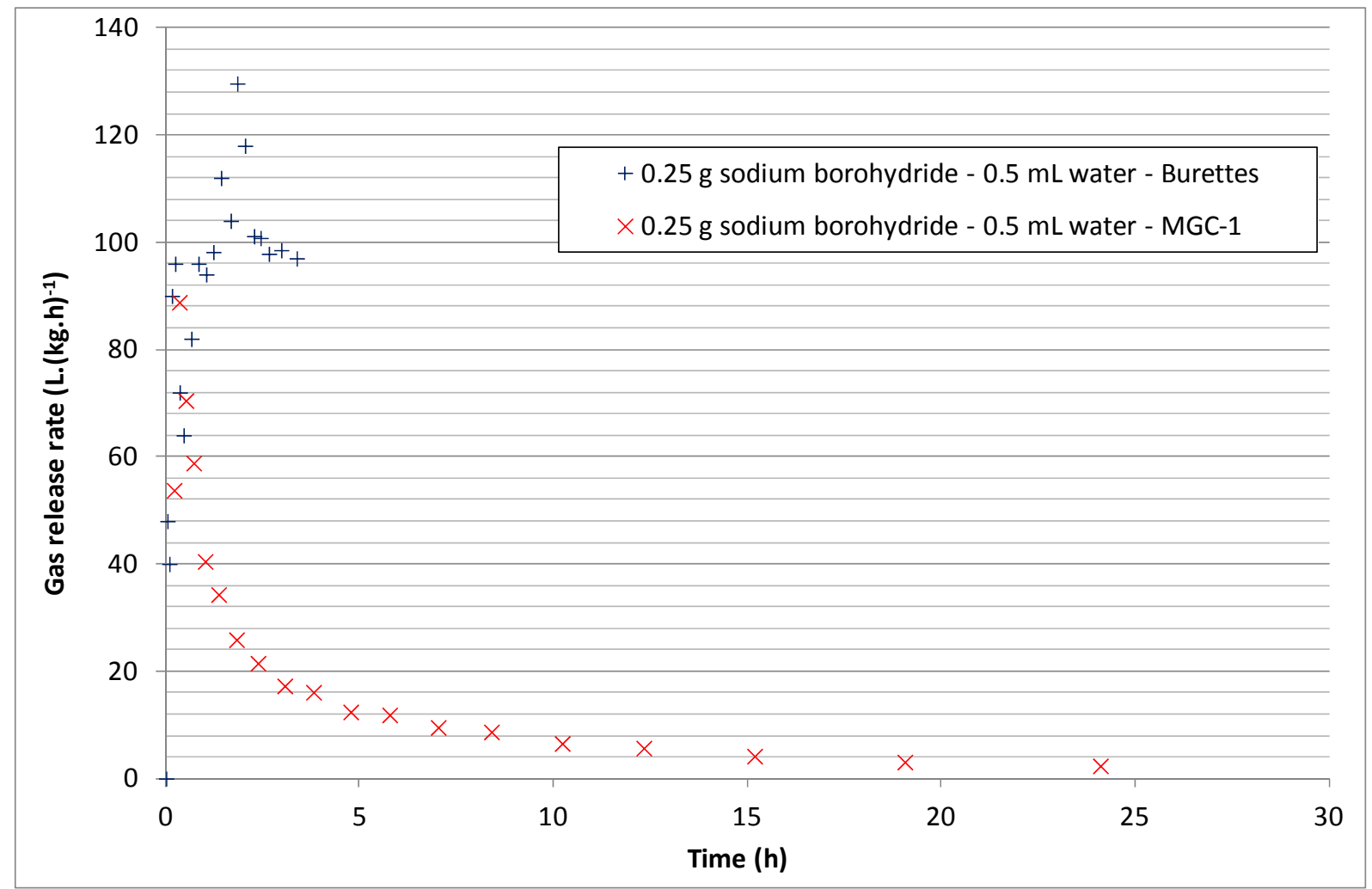

Figure 8: Gas flow rate obtained with sodium borohydride - water/sample mass ratio of 2. 


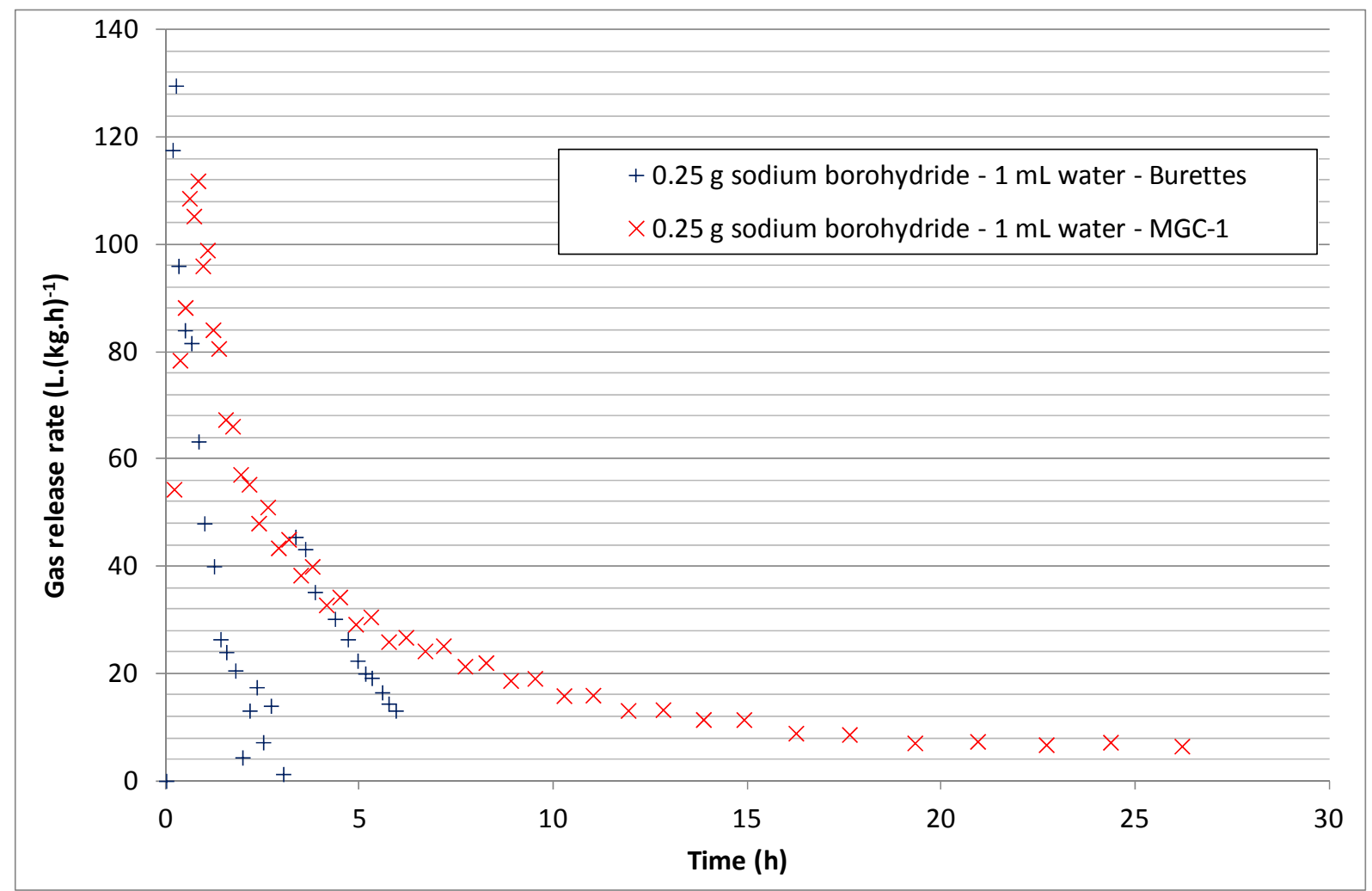

Figure 9: Gas flow rate obtained with sodium borohydride - water/sample mass ratio of 4. 


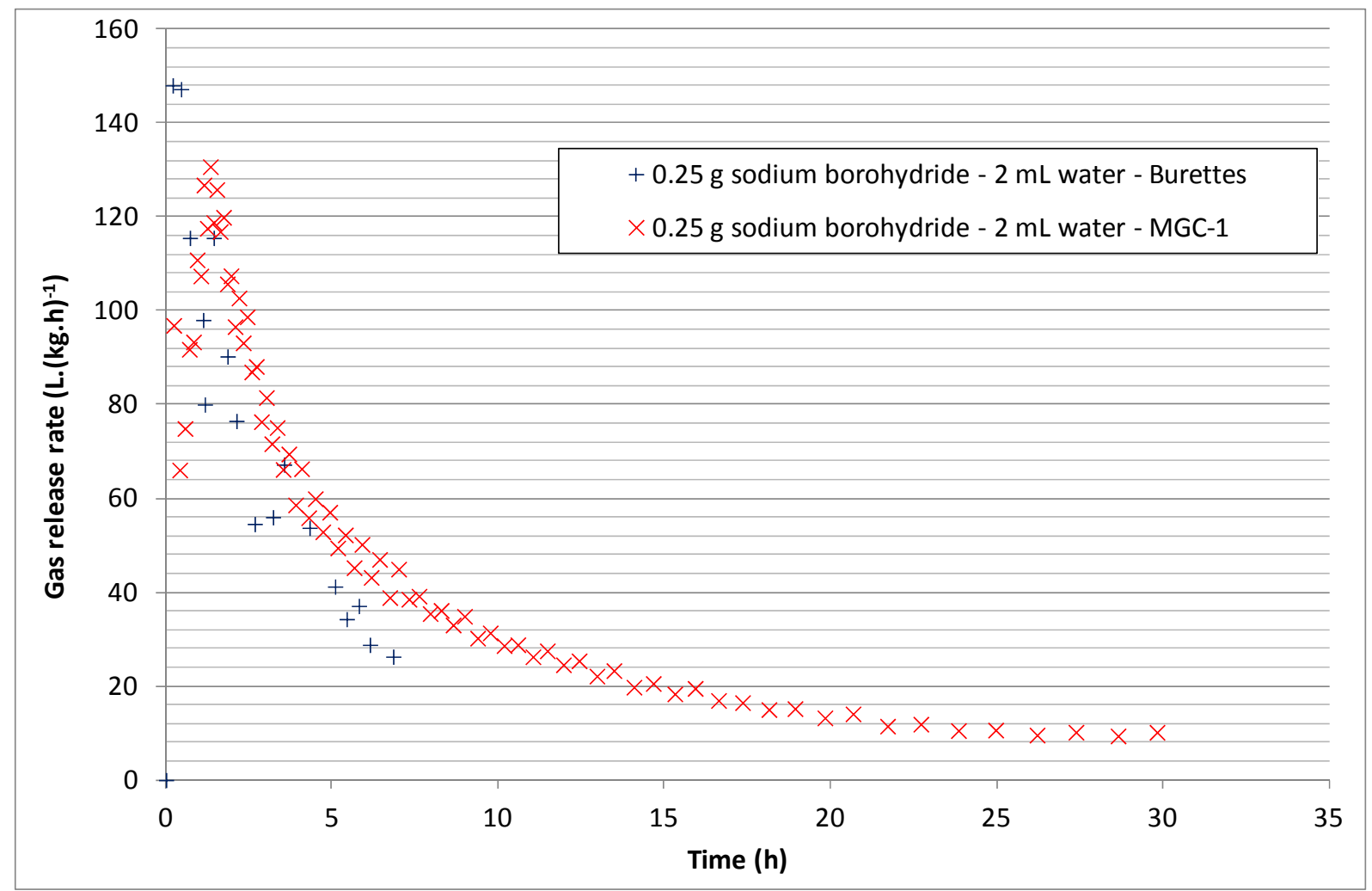

Figure 10: Gas flow rate obtained with sodium borohydride - water/sample mass ratio of 8 .

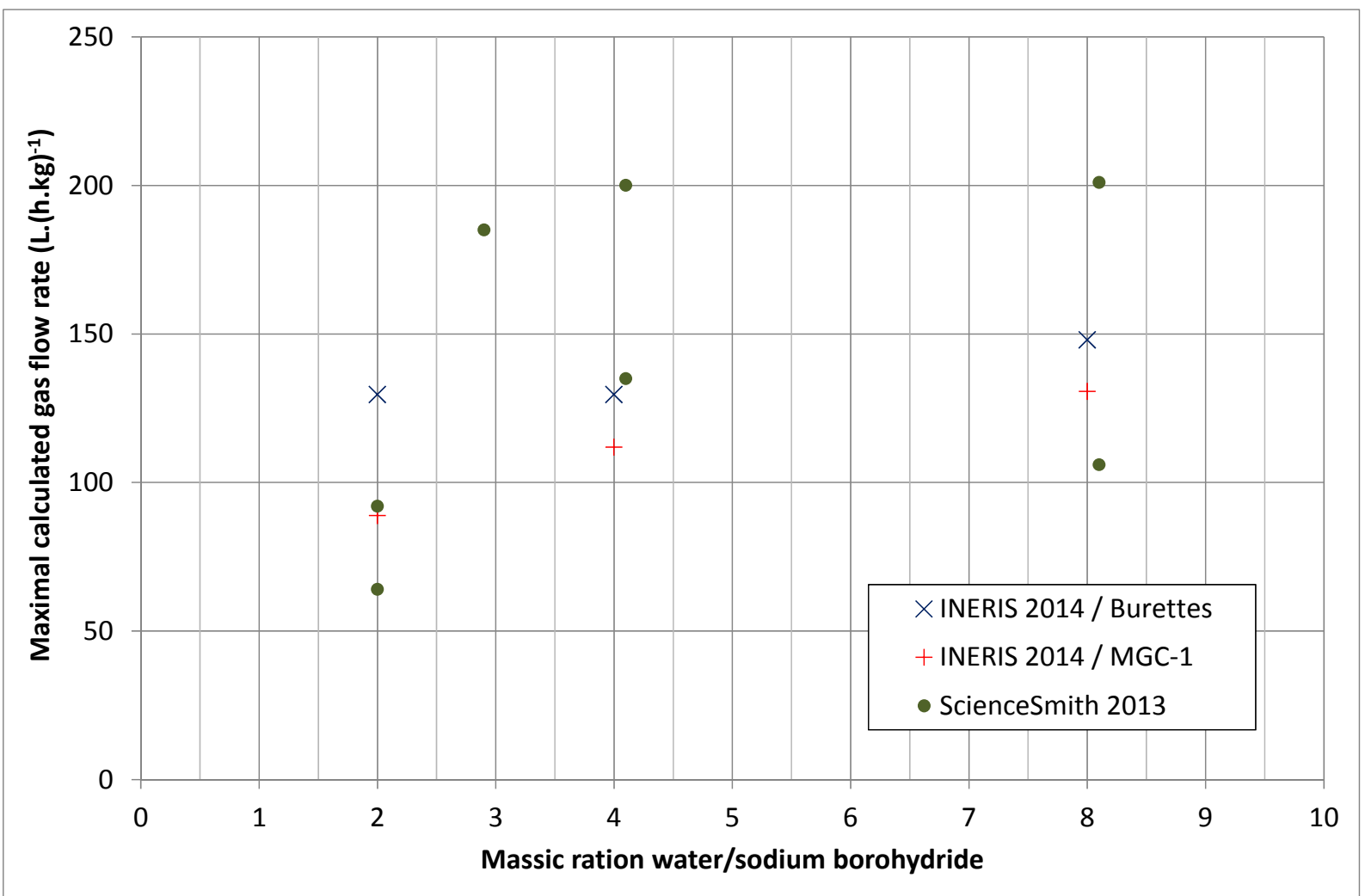

Figure 11: Comparison of gas flow rate obtained with sodium borohydride as a function of water/sample mass ratio. 